\title{
SPATIAL COORDINATES IN BUILDING THE BRAND IMAGE OF REGIONAL METROPOLISES. THE CASE OF IAŞI MUNICIPALITY
}

\author{
Octavian GROZA ${ }^{11}$, Lydia COUDROY DE LILLE²), Mădălina PAFTALĂ- \\ CIUBOTĂRIȚA ${ }^{3)}$ \\ 1) Cuguat-TIGRIS, "Alexandru loan Cuza" University, Iaşi, Romania \\ ${ }^{2)}$ Biogéophile, University Lumière Lyon 2, Lyon, France \\ 3) "Alexandru Ioan Cuza" University, laşi, Romania
}

\begin{abstract}
The article explores the spatial dimensions of the brand image building of the cities / regional metropolises, with an application on laşi as a study case. The starting point is represented by the results of the researches in FP7 project EuroBroadMap. Visions of the Europe in the World, which shows that the city of Iaşi has an unfavorable position among the preferences of the Romanian student's questioned, which raises some questions about its role as a regional metropolis. In order to improve its position, the city could appeal to the territorial marketing strategies. In this direction, using the results of some field surveys, the article studies the opportunities for structuring a brand image depending on the spatial structure of the symbolic characteristics of laşi.
\end{abstract}

Key Words: regional city, territorial marketing, city lovemark

\section{Introduction}

The collapse of the communist regimes has permitted the reconnection of all national urban systems and a fast creation of a system of European cities which, boosted by the globalization processes, had entered immediately into a competition with each other. This competition is based on the power relationships that describe the efforts to selective attraction of the activities, investments, labor and equipment (Equipe PARIS, 1993). In this tense relational field, the metropolitanisation degree of regional or national urban systems is the parameter that ensures the success or failure of integration of the cities in the international trends of economic exchanges, migratory, intellectual, travel and cultural. The urban systems in Eastern Europe are less metropolized and therefore less prepared to face the demands of globalization and Europeanization, but local authorities have become sensitive to this and begin to act consequently (Coudroy de Lille, 2005).

For regional metropolises, or rather for regional cities - although the terms are still confused (Bailoni, 2008), to exist means to be known and be well placed as active poles for international flows. An ongoing study, FP7 EuroBroadMap. Visions of the Europe in the World ${ }^{1}$, based on the analysis of the answers of over 10.000 students from around the world, shows a clear break between the attractiveness of cities in Western and Eastern Europe. The Research Center CUGUAT-TIGRIS, responsible for the research of the situation in Eastern European Union, has made surveys in two university centers, laşi and Bucharest, interviewed between

1) The study is made by an international consortium composed by European teams (from Belgium, France, Malta, Portugal, Romania, Sweden, Hungary), Asian (China, India, Turkey), African (Cameroon) and South American (Brazil) and at this stage it follows the vision that students have about the states and cities of the world, analyzed according to their knowledge (number of occurrences in responses) and their attractiveness / non-attractiveness (Like to Live / Not like to Live); http://www.eurobroadmap.eu 
October to December 2009 a total of 439 students from different majors fields (social sciences, political sciences, business, health, arts, engineering). The preferences to live in different cities and their degree of knowledge (Fig.1) shows the same difference between Eastern and Western Europe, but also differences within Romania. Thus, Bucharest, Braşov and Sibiu are better known and liked than the city of laşi.

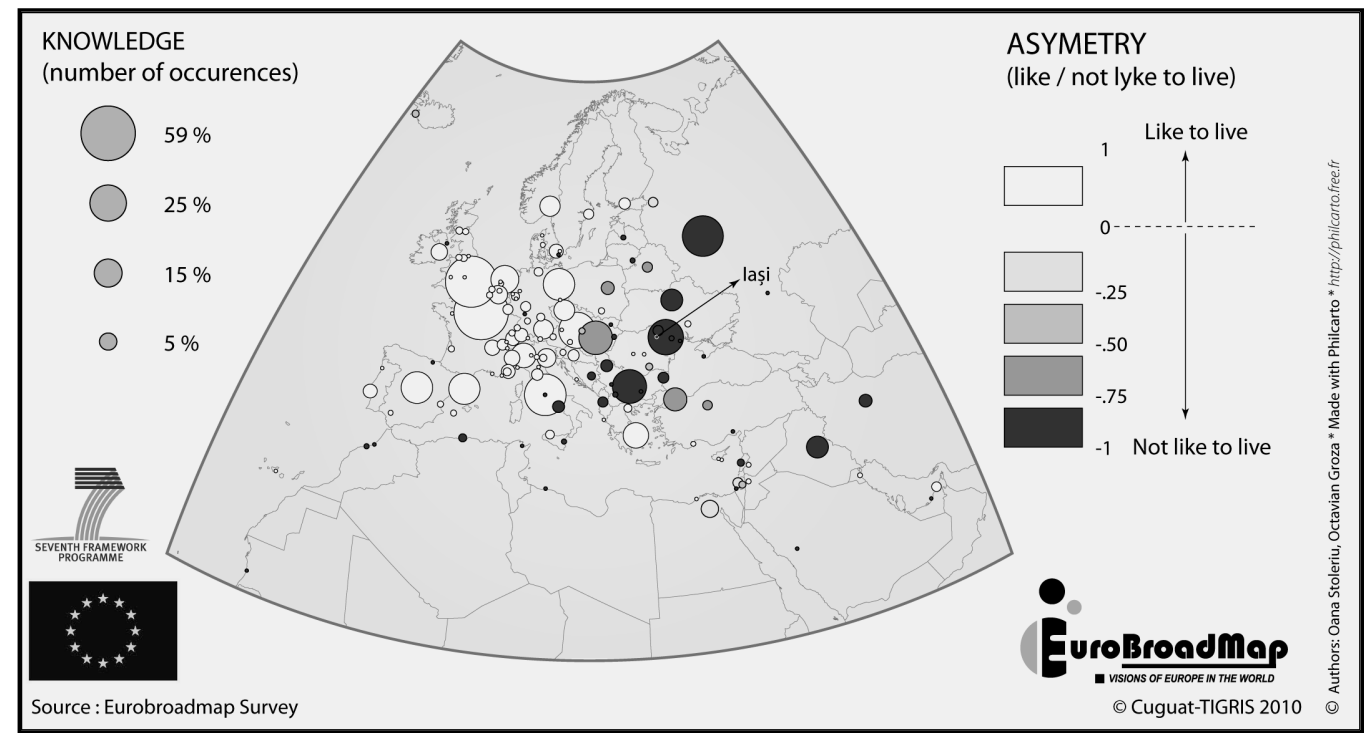

Fig. 1 - laşi in the field of the preferences of the Romanian students

This last finding, in apparent contradiction with the position of regional metropolis of laşi, raises the question of territorial marketing strategies that must apply to regional towns to improve the position / the image in the urban systems organized at different spatial scales. In this article we will not consider elements somehow objectives (resources, population, equipments, infrastructures) that can be mobilized in these strategies but cultural ones (identity values, historical heritage), cumulated on long-term, and which have therefore a character much less conjuncturale than the first one. These resources did not exist than in extent they are mobilized by territorial actors whose work seeks clearly the territory development (Gumuchian et al., 2003). Generally we can speak of the existence of two types of resources (Pecqueur, 2003, 2004): generic resources (their value is independent of their participation in any production process) and specific resources (exist as such but their value depends on their use).

The attractiveness of a territory, and especially her permanence, are stronger once the territory has more resources and more specific assets (Pecqueur, ibid.). The question therefore is the knowledge of the specific resources of the city and the estimate of their ability to be mobilized by marketing strategies to build / strengthen a territorial particularity able to provide the insertion of the municipality in the national and European urban system. Once built (structured), the territorial specificity is not enough in itself to serve the purpose of the territorial marketing strategies - it must be communicated. The communication process involves first the finding of the elements of visual identity easy to transform into a message which can transmits immediately to the receiver a number of positive associations of ideas, intended to structure an image as nearest as the realities of the respective territory. Therefore, the brand image of a 
place is very close to the economic notion of brand marketing. Gardner \& Levy (1955) assert that the brand is "a complex symbol representing a variety of ideas and attributes, that notify the consumer about several things, not only by how it "sounds" (and by literary significance, if it has it) but, more important, by the complex combinations that he built it and acquired it as a public object during a certain time"2). According to Keller (1997, 2003) "what distinguishes a brand by an article without a brand and what gives him a economic value is the sum of consumer's perceptions and feelings about the product attributes and how to materialize them, at the brand name and what represents it and about the company associated to the brand", the brand being "a set of mental associations held by a consumer, which increase the perceived value of a product or service"3).

In the territorial marketing, the visual identity elements are components of the territorial complex and, mostly, they describe his symbolic dimension (Table 1). The diversity of situations, due to the many possibilities of combining in situ these components, combined with the diversity of perceptions of the target audience makes very difficult to choose the most suitable elements, capable to focus and to submit in a quickly assimilable form the essence of the territory in question.

Table 1

The territorial mix

\begin{tabular}{|l|l|}
\hline \multicolumn{1}{|c|}{ Components } & \multicolumn{1}{c|}{ Variables } \\
\hline Organic component & $\begin{array}{l}\text { The history of territory: the origin of the population, its role in } \\
\text { country's history ... } \\
\text { The culture: progressive traditions, conservative ones, ancient } \\
\text { rituals, traditions, religion.... } \\
\text { The current organization of the territory: the share of territory in } \\
\text { the region, neighbouring cities, the locating of public services ... }\end{array}$ \\
\hline Economic component & $\begin{array}{l}\text { Historical studies on the dominant economic activities } \\
\text { Current economic diagnosis }\end{array}$ \\
\hline Geographic component & $\begin{array}{l}\text { Impact of geographic conditions (relief, climate ....) on the identity } \\
\text { of people, locating of economic activities }\end{array}$ \\
\hline Symbolic component & $\begin{array}{l}\text { The visual identity of the territory: } \\
\text { - Landscapes (forest, mountain, parks ....) } \\
\text { - Old and new architecture (castles, palaces, churches, factories ...) }\end{array}$ \\
\hline
\end{tabular}

Source: Girad-Millet V., 1995.

In this context, the designing of a necessary methodology finding the items with the highest visual impact, and affective of course, proves quite complicated. The most stable landmarks of such methodology should be searched first in the imaginary constructions already existing on the studied territory, and secondly in the ultimate goal pursued by the territorial marketing strategies. In the ideal case, the goal of these strategies should aim to crystallize a lovemark (Fig. 2), which combines the highest proportions, the affectivity and the respect of the target audience.

2) Quoted by Avasilcăi and Huțu, 2005, p. 18-19.

3) Quoted by Avasilcăi and Huțu, 2005, p. 18-19 
Unlike economic marketing strategies, those of the territorial marketing have more difficulties to overcome, one of the most obvious being the one raised by the geographical scale of projection. If the respect for a particular place is less sensitive to the effect of distance and scale, affectivity is instead highly related to the attendance at that place, its actual knowledge, or the attendance and the knowledge are relatively to the proximity and accessibility. In the process of building the brand image the respect can be a force strong enough to act subsequently as a magnet for the target audience, which will thus be tempted to discover that location and, in case of a joyful experience, to integrate it into their emotional world.

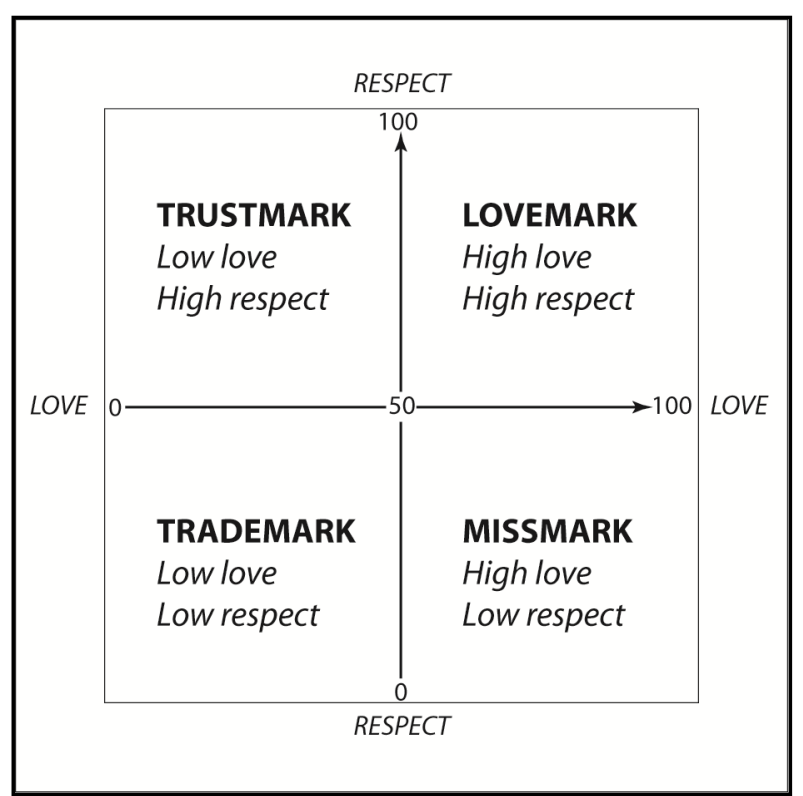

Fig. 2 - Marks categories (Samama, 2003, modified)

For this to happen it needs that the elements of visual identity selected lead to a brand image matching to the goal and respect rigorously their functions (function of differentiation, competition, spatial organization, promotion, etc.), with primary emphasis on the guarantee of quality. It is relatively simple for a brand image to create simple and powerful differentiations in the imaginary of the target audience, but it is harder for her to respect two fundamental dimensions: relevance and credibility, both describing in fact the guarantee of the territory quality that it promotes. The image promoted outside the city must accord with the image that the people of that urban settlement have.

The significant differences between "the promoted city" and "the living city" put the visitor in difficulty, leading to a decreasing of confidence in the "bought" product.

This article is structured on a crucial question, which arises from the previous assertions: what are the elements that a regional metropolis should use to build her brand image so that she minimizes the risks to promote an image that does not correspond to the local realities? 


\section{Material and Methods}

This study is based on an inquiry which was realized from March to June 2010, on a sample of 135 subjects through the interviews face to face at the subjects address and via the Internet, by posting the questionnaire on the website www.esurveyspro.com (Paftală-Ciubotărița, 2010). 45 persons were male respondents (33\%) and 90 female individuals $(67 \%)$, aged over 18 years, residing in the city of laşi (74) or in other localities, urban or rural (61), most part from Moldova.

\section{Sample structure}

Table 2

\begin{tabular}{|l|r|l|r|l|r|}
\hline Ages (years) & Number & $\begin{array}{l}\text { Level of } \\
\text { education }\end{array}$ & Number & Profession & Number \\
\hline $18-25$ & 50 & $\begin{array}{l}\text { Elementary } \\
\text { school }\end{array}$ & 4 & High skilled professions & 76 \\
\hline $26-35$ & 39 & High-school & 21 & Intermediate professions & 5 \\
\hline $36-45$ & 26 & University & 79 & Office employees & 14 \\
\hline $46-$ over 60 & 20 & Postgraduate & 32 & Workers & 6 \\
\hline & & & Students & 26 \\
\cline { 4 - 5 } & & & Unemployed & 6 \\
\cline { 3 - 5 } & & & Retired & 2 \\
\hline
\end{tabular}

The age structure of respondents is relatively uniform, with a predominance of the age category $18-25$ years, which participates with $37 \%$, followed by the age group $26-35$ years (28\%), $36-45$ years $(19 \%)$ and 46 - over 60 years (14\%).

In terms of education level the sample shows a predominance of persons with advanced studies $(58 \%)$, followed by $24 \%$ of respondents with postgraduate studies, $15 \%$ have high school education, the fewest having secondary education $-3 \%$.

The classification by types of occupation was realized based on the socio-professional categories from the nomenclature developed by the National Institute of Statistics, which added three additional classes corresponding to those unemployed. It emerges that $56 \%$ of respondents are included in the category Teaching and higher intellectual professions (teachers and scientific professions, careers in the information area, art and performances, company engineers and technical staff, etc.), $10 \%$ have a profession included in the category Officials (civil servants and staff employed in public service, staff employed in direct services to individuals, etc.), and $19 \%$ are still students.

Regarding the marital status of respondents, $43 \%$ are unmarried, while $57 \%$ are married (among the married ones, $69 \%$ have children, and the remaining $31 \%$ are couples without children). 
People who participated at this survey responded to a questionnaire with 29 closed questions, semi - closed and opened, structured in such a way to allow the notification of general elements and specific ones related to the possible structuring of a brand image of the city laşi and in particular to its promotion.

\section{Results and discussion}

The analysis of responses show that the respondents, originating mostly from Moldova, are very attached to laşi: $99 \%$ of respondents declared they are proud that they are residents or visitors of the city of laşi, $89 \%$ said they are very attached, emotionally of this city, $73 \%$ believe that laşi is a highly respected name, and $42 \%$ could not imagine a world without laşi.

Despite this, the responses show that the respondents do not outbid the place and the role of laşi in the national territory. Thus, questioned on the importance at regional and national scale of the city, $91 \%$ say that the city of laşi is the most important city in Moldova and $99 \%$ gives him the attribute of the most important university center in Moldova, while at national scale, the hierarchies are changing, the most important university center is considered the city of Bucharest (64\%), followed by laşi (25\%) and Cluj-Napoca (10\%).

The respondents are sensitive to the phenomenon of urban competition and have identified as the main competitors of the laşi municipality the city of Cluj-Napoca (82\%), Timişoara (70\%), Braşov (47\%), Bucharest (47\%), Constanța (43\%), Piatra Neamț (32\%), Bacău (30\%), Suceava $(27 \%)$ and Sibiu $(26 \%)$.

The general analysis of the responses reveals a complex image on the city of laşi (Table 3), with some contradictory elements (cheerful city - city where the living is not good / poor town, young city - closed city to the ideas from abroad, etc.).

The composite image and sometimes contradictory of the city

Table 3

\begin{tabular}{|l|l|}
\hline \multicolumn{1}{|c|}{ Positive aspects } & \multicolumn{1}{c|}{ Negative aspects } \\
\hline - Cultural city - $97 \%$ & - High unemployment $(87 \%)$ \\
- Attractive university town - 92\% & - City where the living is not good - $78 \%$ \\
- City with special sightseeings - 92\% & - The current municipal team does not give a \\
- Fositive image to the city - $77 \%$
\end{tabular}


However, are generated several lines of force which can form the base for an effective and equitable territorial marketing strategy. Thus, related with elements of the territorial mix, the responses highlight the cultural $(94 \%)$ and educational $(30 \%)$ dimensions of the municipality, followed by the others: $28 \%$ believe that the historic past of the city is an asset for the city brand image (the capital of Moldova, and later of unoccupied Romania, the town of the three unions, promoter city of the 1989 Revolution), 14\% indicate the natural element as being important in building the image of the city (geographical location, the existence of greenery islands inside the city, and of the woods in the suburbs), $8 \%$ mentions the importance of religious item (relics of St. Cuv. Paraskeva, the approximately 100 churches and monasteries), $5 \%$ believe that the economic activity has an important contribution to the image of the city (the touristic, industry and commercial activity), 5\% remember the traditions and customs kept, $3 \%$ mentions the attribute of medical center, of prime importance, to Moldova and $2 \%$ the "how to be" of the people (open, hospitable, warm).

In the event that each of the respondents (130) would meet with an EU citizen and would understand one with each other in the same language, he would say the following about laşi: laşi is by excellence a cultural and academic city $(50 \%)$, with a special natural and cultural heritage, which suffers from the disinterest of the authorities and the negligence of the citizens $(28 \%)$, a city with a rich and brilliant history $(17 \%)$, a city with charm, beautiful, happy, bohemian, which combines tradition with modernity, a quiet town, secure, civilized, young $(35 \%)$, with welcoming people, quiet, open to new, well-trained in various fields $(15 \%)$. The geographical location (4\%) and the traditional cuisine, with quality wines and dishes (2\%), represent as many positive aspects that must be said.

To promote a more attractive image, in the 106 valid responses, the visual elements most quoted refer to the architectural monuments (The Palace of Culture - 62\%, The Metropolitan Cathedral - 23\%, The Three Holy Hierarchs Monastery - 20\%, The National Theatre "Vasile Alecsandri" - $17 \%$, The Cetățuia Monastery - 10\%, various architectural monuments with a special architecture - 23\%, The Golia Monastery - 6\%, The Galata Monastery - 5\%), cultural elements ("Alexandru loan Cuza" University - 36\%, The Central University Library "Mihai Eminescu" - 9\%, The lon Creangă Memorial House - 9\%, the museums - 5\%), natural elements (The Botanical Garden - 29\% The Copou Gardens and the Carol I Avenue - 25\%, Mihai Eminescu's Linden Tree - 16\%, the green spaces, generally, - 13\%), religious items ( the places of worship from laşi - 12\%). Asked about the spontaneous images associated with laşi (Fig. 3), the Palace of Culture stands out clearly, with $71 \%$, followed by The Copou Gardens and the Carol I Avenue (42\%), the "Alexandru Ioan Cuza" University (34\%), the Cathedral Metropolitan (28\%), the Botanical Garden "Anastasie Fătu" (14\%) and by the Three Holy Hierarchs Monastery (11\%).

The list includes mainly cultural and educational institutions, which confirms the cultural dimension as a potential force field for a possible marketing strategy. In addition to this question, the respondents had to answer to another one, concerning the monuments that would include in a touristic "Golden Platform" of the town. The responses, mapped in Figure 4, focus the objectives in a central area extended north-west - south-east and displayed on a relatively restricted area. The effect of proximity of these objectives, framed by an appropriate urban policy, can give to the image of laşi a character of relevance and credibility, thereby minimizing the distance between "the promoted city" and its territorial realities.

The urban marketing strategy is based clearly on the cultural dimension of the municipality with her concrete projections in the city area - would have the opportunity to find the exact proportions between affection and respect and would lead to the structuring of a city lovemarks 
Octavian GROZA, Lydia COUDROY DE LILLE, Mădălina PAFTALĂ-CIUBOTĂRIȚA

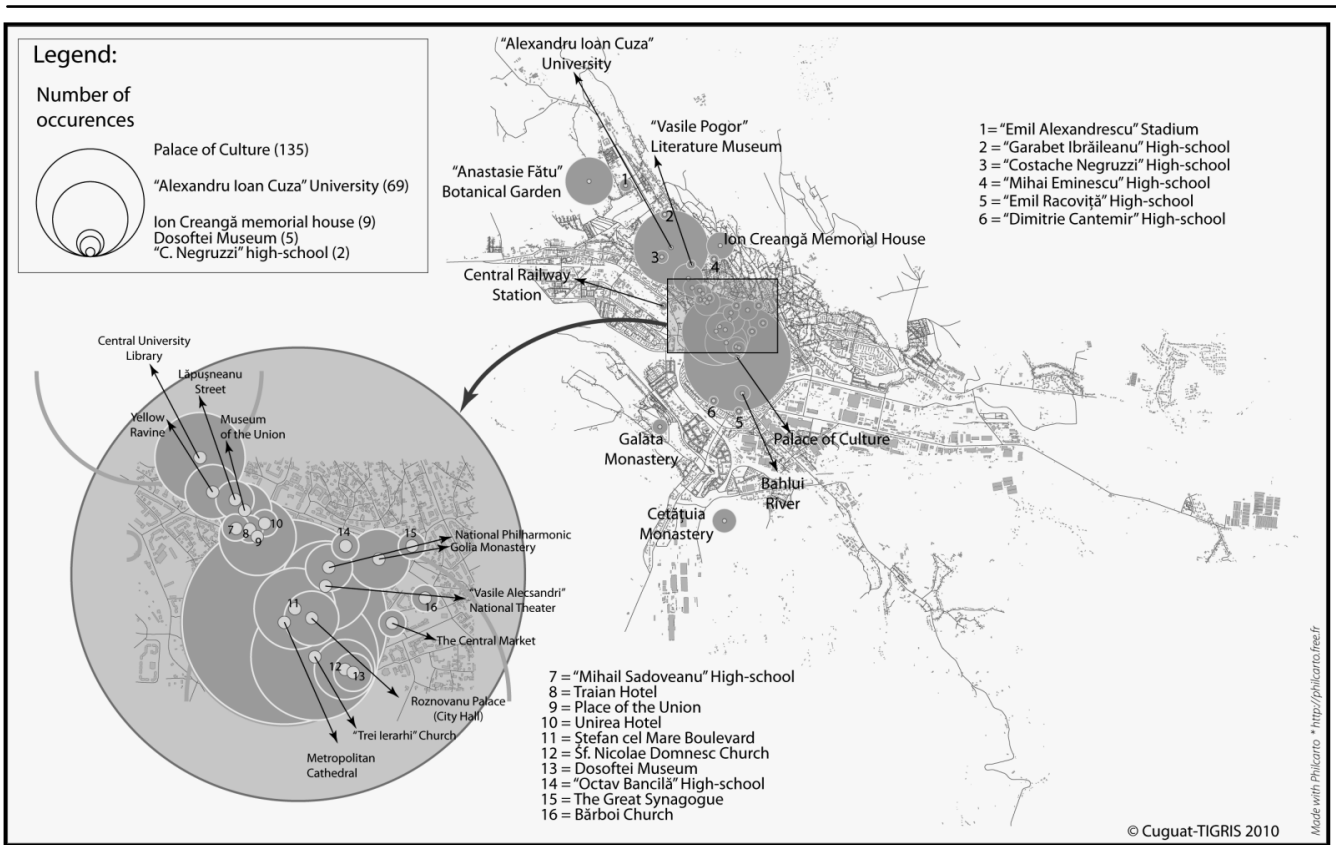

Fig. 3 - The frequency of places associated with the municipality of laşi

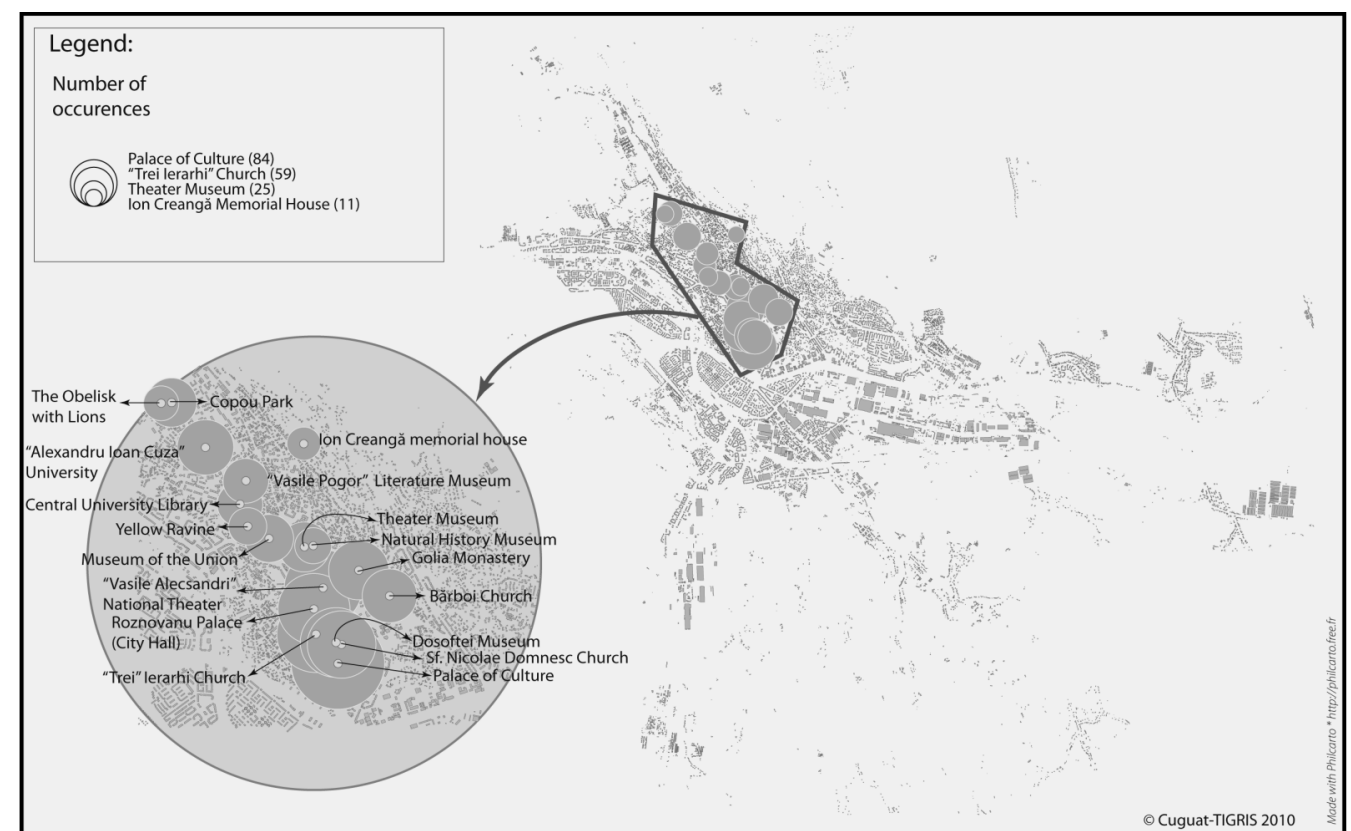

Fig. 4 - The spatial structure of the symbolic capital supporting a possible city lovemark of laşi 
in the true sense of the word.

The promotion of this possible city lovemarks is another matter. The current heraldic symbols related to the laşi municipality (Fig. 5) are less visible in the public space and therefore less known to the respondents, who were unable to recognize the emblem of the county and even of the city. Instead the figure of the Palace of Culture on the anniversary logo of the 600 anniversary of the city facilitated the reception by the respondents that this logo has a clear link with the municipality of laşi.

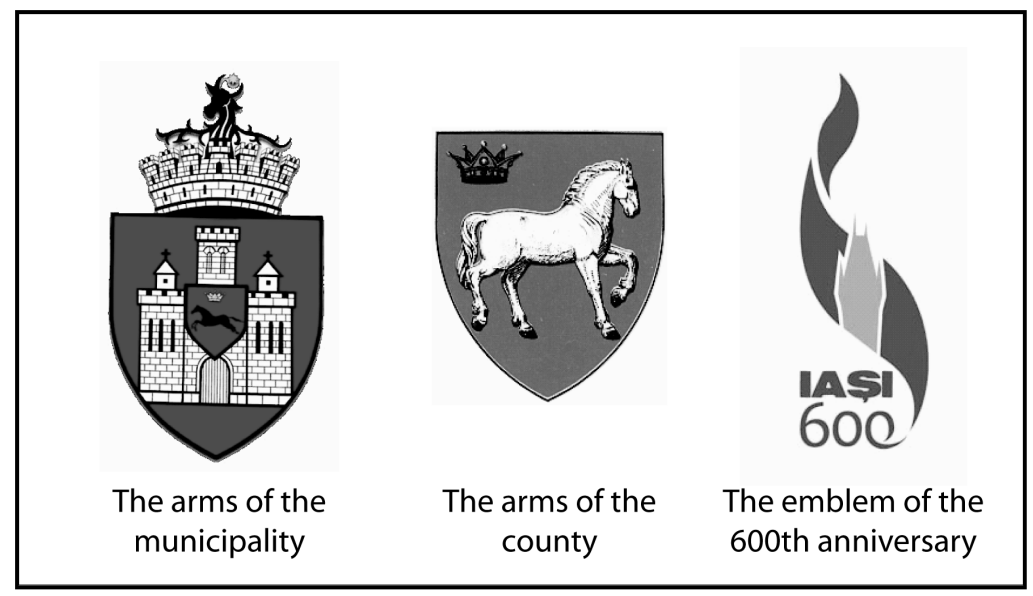

Fig. 5 - The arms and emblems related to the laşi county and to the laşi municipality

Continuing this idea, the questionnaire sought to capture the existence of some general symbols, very present in the collective mind. The question was semi-opened, being offered 19 versions of answer (constructions, sites, personalities) of which the respondents had to choose the ten most representative, and to note them, from 1 to 10 (10 - the most representative, 1 less representative). At this question there were 101 valid responses. After analyzing the responses (Fig. 6), it is clear that the most representative symbol of laşi, in accordance with the freely expressed opinions, is the Palace of Culture (54\%), other possible symbols being the Metropolitan Cathedral, which houses the relics of Saint Paraskeve $(24 \%)$, The "Alexandru Ioan Cuza" University (10\%), The Three Holy Hierarchs Monastery (4\%) and The Botanical Garden (3\%).

Located within the Golden Platform, these objectives are also relevant to the municipality according to the 120 of the respondents, who consider that the promotion of the city should be based on the cultural heritage (81\%), on the fact that is a cultural, historical and academic city $(31 \%)$, with quality and cheap touristic services $-7 \%$.

The Palace of Culture, currently insufficiently visual promoted, can be officially a symbolic image of the city because the associations of ideas that he induces to the viewer's mental, surprise happily the dominant traits of the city, like they emerge from the responses analyzed. In addition, his image synthesize very well the functions of a brand image (differentiation, competition, promotion ...), being credible and relevant for the municipality of laşi. 


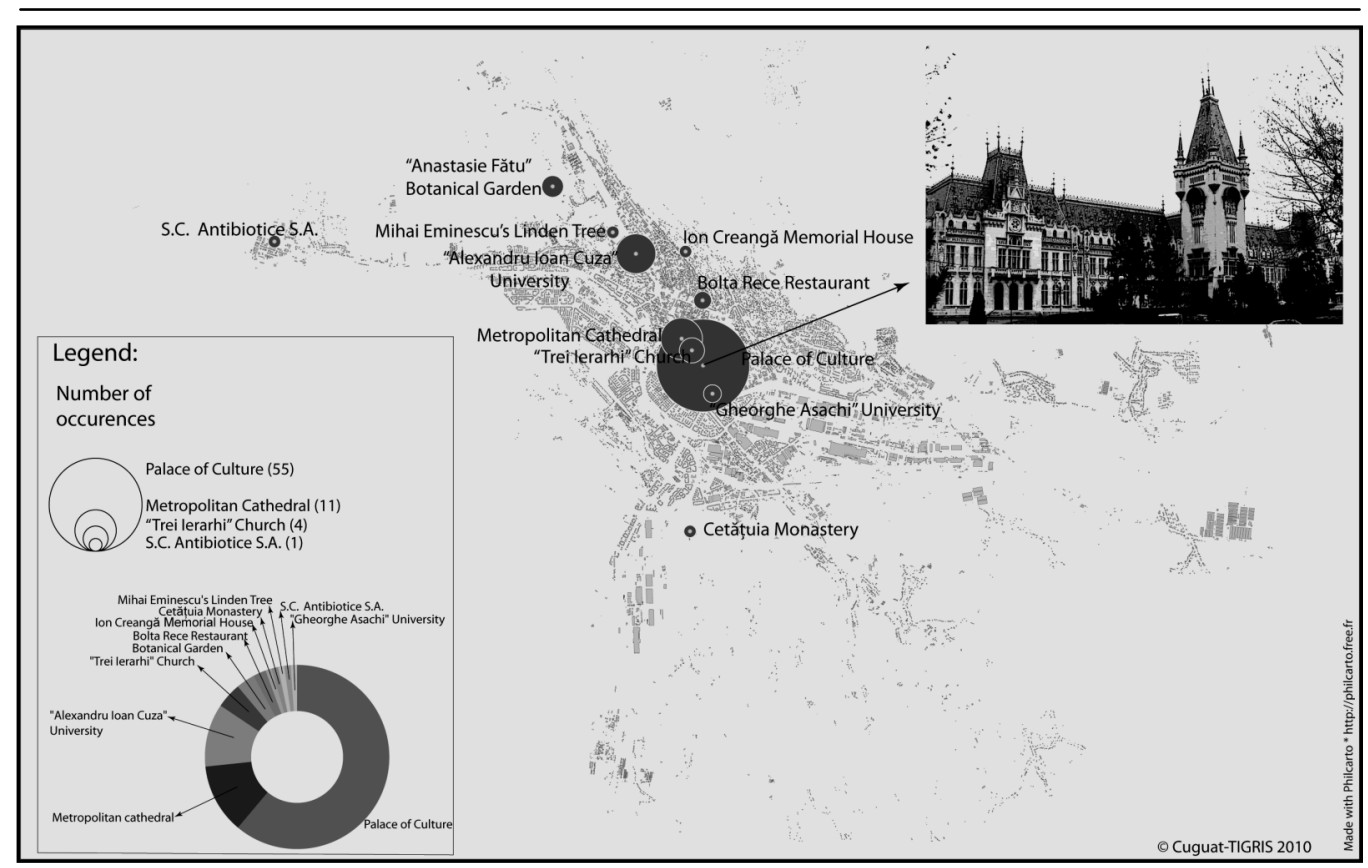

Fig.6 - The most frequent symbols associated with laşi municipality

\section{Conclusion}

„With a single flower is not possible to make the springtime” says a Romanian proverb. The brand image of a city can not be built, maintained and circulated based on a single objective, on a single symbol. The research carried out in this article demonstrates that the spatial dimension of the symbolism of urban territory is very important in creating a credible brand image. A city-lovemark can not be built without the truths of the urban space and without the freedom and pleasure of the visitor to find itself that he was not wrong giving confidence to an image. In case of the cities that have experienced the pressure of the communist government and in which the modernities have often remained unfinished dreams (Groza, 2001; Stoleriu, 2008 ) it is difficult to achieve the necessary balance between the cognitive, moral and aesthetic space (Bauman 1995). The proximity in the urban space of the symbolic targets, loaded by past and traditions, may be helpful in finding this balance, but it is not the solution itself, because, as apparent from the investigation, the behavior in public space, education, kindness, hospitality and the opening of people put their mark on the perception of the stranger about that location, on its future mental constructions focusing, usually around the first impression.

\section{References}

AVASILCĂI S., HUȚU, C. A. (2005), Managementul și marketingul produsului. Branding, Ed. Venus, lași, 108 p.

BAILONI M. (2008), La Northern Way et les city-regions: vers une nouvelle approche politique du territoire régional en Angleterre ?, in Géocarrefour, Vol. 83/2: Mutations et inerties spatiales dans le Royaume-Uni d'aujourd'hui, p.141-150 .

BAUMAN, Z. (1995) - Postmodern ethics, Blackwell Publishers, London, trad. In 
Romanian: Etica postmodernă, Editura Amarcord, Timişoara, 2000.

COUDROY DE LILLE L.; WOLANIUK A. (2005), Lodz, ou les ressources territoriales d'une stratégie métropolitaine, in Géocarrefour, Vol. 80/1: La Pologne dans l'Europe d'aujourd'hui, p.35-48.

EQUIPE PARIS (1993), Le poids économique des villes dans le système urbain européen, in Sallez A. (dir.), Les villes lieux d'Europe, La Tour d'Aigues, Editions de l'Aube, p.19-64.

GIRARD-MILLET V. (1995), Identité territoriale et marketing territorial: application du concept de Corporate Mixin, Les cahiers Lyonnais de recherche en gestion, 16, p. 148-172.

GROZA O. (2001), Centralité, identité et différenciation dans le système des villes roumaines, Analele Ştiințifice ale Universității „Alexandru Ioan Cuza” laşi, serie nouă, tomul XLVII, s. II. c., Geografie, Editura Universității „Alexandru Ioan Cuza” Iaşi, p. 40-59.

GUMUCHIAN H. et al. (2003), Les acteurs oubliés du territoire, Anthropos, Paris, 185 p.

PAFTALĂ-CIUBOTĂRIȚA M. (2010), Crearea imaginii de marcă a Municipiului laşi, dizertație masterală, Facultatea de Geografie-Geologie, Universitatea „Alexandru loan Cuza”, iulie 2010, laşi, 182 p.

PECQUEUR B. (2003), Dans quelles conditions les objets patrimoniaux peuvent-ils être support d'activité?, XIII ${ }^{\mathrm{e}}$ conférence internationale du RESER, Services et développement régional.

PECQUEUR B. (2004), Vers une géographie économique et culturelle autour de la notion de territoire, Géographie et cultures, 49, p.71-86.

SAMAMA A. (2003), De l'importance aujourd'hui de passer de la marque image à la marque, Revue Française de Marketing, 192/193, p. 80 - 81.

STOLERIU O. M. (2008), Evoluția uman-geografică şi urbanistică a oraşului laşi în perioada postbelică, Editura Terra Nostra, laşi, 265 p.

Received at : 8.04.2010

Revised at: 13.05.2010

Accepted for publication at: 15.06.2010 
